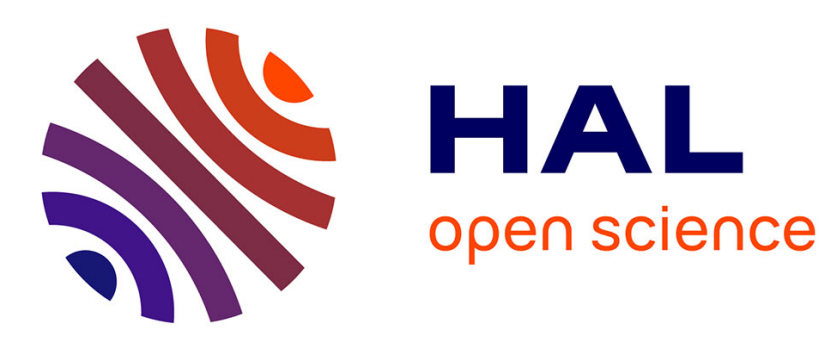

\title{
On the Contingency of Equilibrium Exchange Rates with Time - Consistent Economic Policies
}

Antoine Bouveret, Bruno Ducoudre

\section{To cite this version:}

Antoine Bouveret, Bruno Ducoudre. On the Contingency of Equilibrium Exchange Rates with Time

- Consistent Economic Policies. 2007. hal-01066080

\section{HAL Id: hal-01066080 \\ https://hal-sciencespo.archives-ouvertes.fr/hal-01066080}

Preprint submitted on 19 Sep 2014

HAL is a multi-disciplinary open access archive for the deposit and dissemination of scientific research documents, whether they are published or not. The documents may come from teaching and research institutions in France or abroad, or from public or private research centers.
L'archive ouverte pluridisciplinaire HAL, est destinée au dépôt et à la diffusion de documents scientifiques de niveau recherche, publiés ou non, émanant des établissements d'enseignement et de recherche français ou étrangers, des laboratoires publics ou privés. 


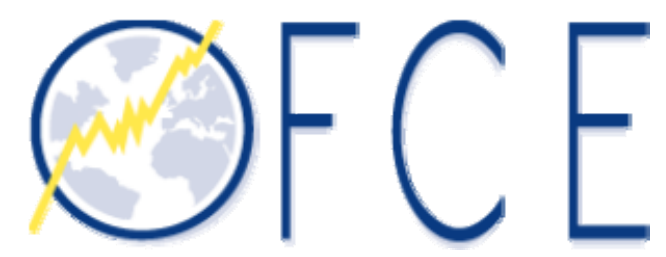

\section{Document de travail}

\section{ON THE CONTINGENCY OF EQUILIBRIUM EXCHANGE \\ Rates With Time- Consistent Economic Policies}

$\mathbf{N}^{\circ}$ 2007-08

March 2007

Antoine BOUVERET

OFCE

Bruno DUCOUDRE

OFCE 


\title{
On the Contingency of Equilibrium Exchange Rates with Time- Consistent Economic Policies*
}

\author{
Antoine Bouveret ${ }^{\dagger}$ and Bruno Ducoudré ${ }^{\ddagger}$
}

\begin{abstract}
Equilibrium exchange rate theories (FEER, BEER and NATREX) make the assumption that the Real Equilibrium Exchange Rate (RER) is independent from internal equilibrium and economic policies. We develop a model in which economic policies depend on the minimisation of an intertemporal loss function, and we show that in a Wage Setting-Price Setting (WS-PS) framework, the RER depends on the policymakers' objectives, making the previous assumptions highly questionable. We provide some results for the impact of policymakers' preferences on the long run exchange rate and discuss the concept of inflation illusion. In our model, the long run (equilibrium) exchange rate is contingent on policymakers' preferences, implying that equilibrium exchange rate estimates must be treated with great caution.
\end{abstract}

JEL Codes : F31, F32, F41, F42

Keywords: Equilibrium Exchange Rates, Time-Consistent Policies, Long-Term Interest Rate

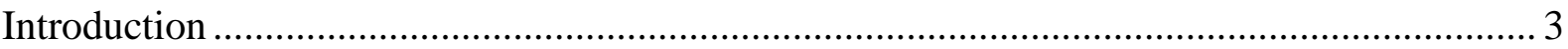

Part I: Economic Policies, Long-term interest rates and the RER …................................... 3

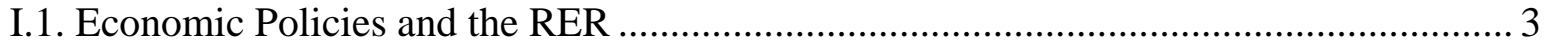

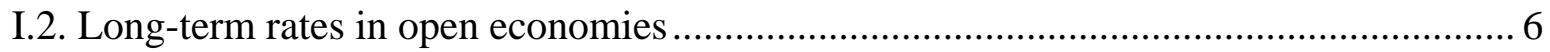

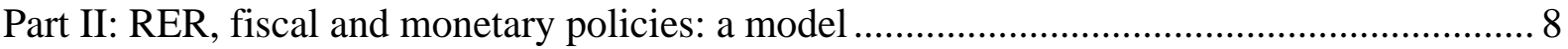

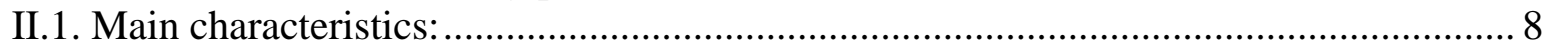

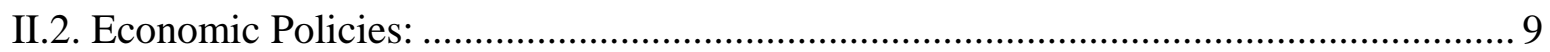

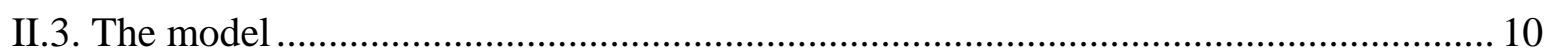

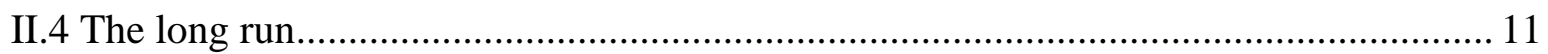

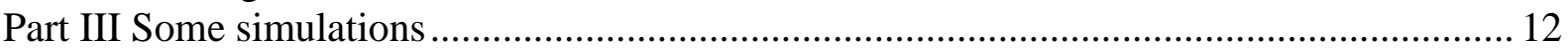

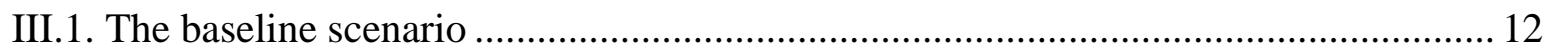

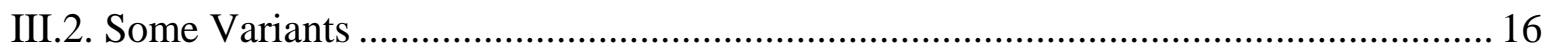

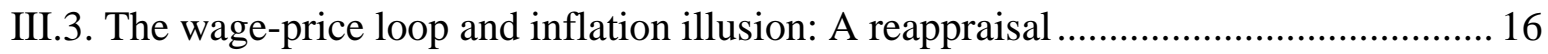

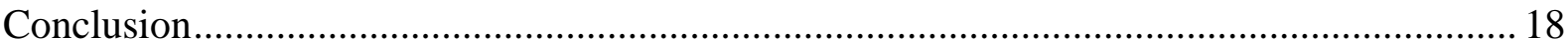

Annex I. Solution of RE linear models with time consistent policy and two authorities ........ 19

\footnotetext{
* We thank Henri Sterdyniak for providing us with helpful advice.

† Ph.D student at OFCE, antoine.bouveret@ofce.sciences-po.fr, 69 Quai d’Orsay 75007 Paris.

₹ Ph.D student at OFCE, bruno.ducoudre@ofce.sciences-po.fr.
} 


\section{Introduction}

This paper aims at analyzing the relationship between the real equilibrium exchange rate (RER), long-term interest rates and economic policy.

Equilibrium exchange rate theories (FEER, BEER and NATREX) do not take economic policies into account. The RER is assumed to be independent from the latter. Thus, in the FEER framework, the internal equilibrium is achieved through economic policies and is therefore not affected by the level of the real exchange rate. The independence of RER and economic policies is debatable and depends on questionable hypotheses. First, agents are riskneutral when they manage their portfolio. Following a trade balance deficit, the stock of financial assets adjusts without any specific effect on interest rates. Yet this assumption does not seem compatible with the existence of a home bias toward domestic assets. Several studies ${ }^{1}$ have also shown that national interest rates do not converge to a world level. The Central Bank (CB) can therefore influence interest rates over the long run, taking advantage of the relative independence of domestic and global financial markets. If there is an inflation/unemployment trade-off, the CB can choose its RER (Bleuze and Sterdyniak (1988); Capoen and Villa (1998)). In this framework, for each inflation/unemployment objective pursued by the authorities there is a corresponding (and different) RER. In addition, the RER strongly depends on the goods market equilibrium through the trade balance, which is affected by fiscal policy. The government determines fiscal deficit and public debt levels. The fiscal authority then interacts with the $\mathrm{CB}$ to achieve goods market equilibrium, hence the RER.

We put forward a model in which economic policies (fiscal and monetary) result from the minimisation of an intertemporal loss function, in contradiction with the Taylor's rule. We use a modified version of the Söderlind (1999) program that computes consistent policies ${ }^{2}$ for linear rational expectations models with two authorities. The model is used to analyse the relationship between RER and economic policies' objectives. We show that the RER is contingent upon policymakers' preferences.

The paper is organized as follows: part I provides a selective review of the relevant literature, part II describes the model and part III focuses on various specifications of economic policies and their impact on the RER.

\section{Part I: Economic Policies, Long-term interest rates and the RER}

\section{I.1. Economic Policies and the RER}

\section{RER and internal equilibrium}

Equilibrium exchange rate theories (Williamson (1985); Clark and MacDonald (1998), Stein and Allen (1995)) define the RER as the real exchange rate that achieves both internal

\footnotetext{
${ }^{1}$ See Cumby and Obstfeld (1982), Mishkin (1984), Kasman and Pigott (1988), Frankel (1991), Blundell-Wignall and Browne (1991), Pigott (1993), Throop (1994).

${ }^{2}$ There is no inconsistency of optimal plans in the meaning of Kydland and Prescott (1977). See also Oudiz and Sachs (1984).
} 
and external equilibriums. Internal equilibrium (output equals its potential) is assumed to be reached through economic policies, whereas external equilibrium depends on the RER. Those theories assume that the RER has no impact on internal equilibrium. However, in a Wage Setting-Price Setting (WS-PS) framework, the level of the RER affects the internal equilibrium (Joly and al. (1996); Bouveret and Sterdyniak (2005)).

Assume that consumer prices $p$ depend on wages $w$ and output $y$ according to $^{3}: p_{t}=w_{t}+\alpha y_{t}$, and that wages depend on consumer prices : $w_{t}=l_{t}+n\left(p_{t}^{*}+s_{t}\right)+(1-n) p_{t}+\beta y_{t}$. The real exchange rate $(q)$ is fixed by wages and price dynamics:

$$
q_{t}=s_{t}-p_{t}+p_{t}^{*}=-\left(l_{t}+(\alpha+\beta) y_{t}\right) / n
$$

$s$ is the nominal exchange rate, $p^{*}$ is the foreign consumer price index and $l$ sums workers' demands up. The RER is then a decreasing function of output and workers' demands.

The medium run trade balance is defined by:

$$
\overline{b c}=n \bar{y}^{*}-n \bar{y}+n \delta \bar{q}
$$

Combining (1) and (2) gives output and the RER: $\bar{y}=-(n \bar{q}+l) /(\alpha+\beta)$. The internal equilibrium is a decreasing function of the RER: a RER appreciation raises the output level. Internal equilibrium is no longer determined by economic policy but by the equilibrium of goods and labour markets and the external constraint. The internal equilibrium depends on the RER.

\section{RER and external equilibrium}

Concerning external equilibrium, the RER must stabilise the net foreign assets position in the long run. We can define it (in \% of GDP) as:

$$
f_{t}=\left(1+i_{t-1}^{*}-\pi_{t}+\left(s_{t}-s_{t-1}\right)\right) \cdot f_{t-1}+b c_{t-1}
$$

where $f_{t}$ stands for Net Foreign Assets (NFA) and $i_{t-1}^{*}$ is the foreign interest rate on external debt.

Hence NFA depends on trade balance and the stock of past external debt, including valuation effects (see Branson (1979) and Bleuze and Sterdyniak (1988)). The real exchange rate must stabilise the external debt in the long run. The RER is affected by the dynamics of the stock of net foreign assets. Taking the dynamics of external debt into account, Artis and Taylor (1993) put forward the concept of "Desired Equilibrium Exchange Rate” (DEER). The DEER improves the FEER by taking desired current account and employment into consideration. Bayoumi and al. (1994) analyse the DEER path when the net foreign assets level is not equal to its desired level. Let us assume that the country is initially indebted by $d_{0}$ and it aims at paying off its debt while maintaining its output level; if $r$ is the gap between the interest rate on the debt and its growth rate and $q$ is the real exchange rate, the debt-dynamics are: $d_{t}=(1+r) d_{t-1}-n \delta q_{t}$. In the long run, the real exchange rate is $q=0$.The path of the real exchange rate must verify:

$\frac{d_{0}}{n \delta}=\sum_{t=1}^{\infty} \frac{q_{t}}{(1+r)_{t}}$

The DEER can be viewed as a constraint on exchange rate paths to the equilibrium level. The authorities can choose a trajectory under this constraint. In this framework, the RER is highly dependent on policymakers' objectives and its level depends on its path.

\footnotetext{
${ }^{3}$ All variables except interest rates are in a logarithmic form.
} 


\section{RER and economic policies}

Equilibrium exchange rate theories also assume that internal equilibrium is reached through economic policies without specifying the latter. Bouveret and Sterdyniak (2005) show that monetary policy specification has an impact on the RER. In NPO models (WS-PS and portfolio ${ }^{4}$ model) the monetary policy design is crucial: if the LM equation is used, after a demand shock, the interest rate will rise to stabilise prices. It reduces output and leads to an exchange rate appreciation so as to achieve trade balance equilibrium and stabilisation of the net foreign assets position. If the CB adopts a Taylor's rule, the inflation level is permanently increased and output level is raised due to the gap between prices and costs. The permanent increase in output brings about a depreciation of the RER so as to reach the external equilibrium. In both cases the RER is contingent upon monetary policy.

We now define inflation as ${ }^{5}$ :

$$
\pi_{t}=\lambda\left(n\left(s_{t}+p_{t}^{*}\right)+(1-n) p_{t}+\mu y_{t}+v(i-\pi)_{t}-p_{t-1}\right)
$$

with $i$ as the nominal short term interest rate and $\pi$ as the inflation rate. We include an effect of the real interest rate on inflation ${ }^{6}$. Output is a decreasing function of the real interest rate and an increasing function of trade balance:

$y_{t}=d-\sigma(i-\pi)_{t}+n \delta q_{t}-n y_{t}$ ( $d$ stands for a demand shock). Net foreign assets stabilisation implies trade balance equilibrium in the long run:

$$
\bar{q}=\frac{\bar{y}}{\delta} .
$$

Hence the RER equals:

$$
\begin{aligned}
& \bar{q}=\frac{(d-\sigma(1-A v) \bar{i})}{\delta-\sigma A(n+\mu \delta)} \\
& A=\frac{\lambda}{1-\lambda+v}
\end{aligned}
$$

The RER depends on the gap between the demand shock and the long-run value of the interest rate. In the LM framework the money market equilibrium implies: $i=\frac{\varepsilon y+p-m}{\beta}$. We assume $\beta=1, \bar{m}=0$, then:

$$
\bar{q}=\frac{\left(d-\sigma(1-A v) \bar{p}^{-}\right)}{(\delta-\sigma A(n+\mu \delta)+\sigma(1-A v) \delta \varepsilon)}=f(\underset{+}{d, \bar{p}})
$$

After a demand shock, the interest rate rises to stabilise prices, increasing the real interest rate and weakening output. That involves a real appreciation of the RER (MNPO Model).

If the CB adopts a Taylor's rule, there is an inflation/output trade-off:

$$
i=\phi y+\rho \pi,
$$

leads to :

\footnotetext{
${ }^{4}$ We define the portfolio model as a model with risk-adverse investors on international financial markets.

${ }^{5} \mathrm{We}$ add the interest rate in the price equation: $p_{t}=w_{t}+\alpha y_{t}+v(i-\pi)_{t}$. Assuming that firms adjust slowly their prices to their desired prices we obtain equation (3).

${ }^{6}$ It can be interpreted as the effect of financial costs faced by firms on their desired price. It implies a long-run effect of interest rates on output and unemployment; see Chagny and al. (2002). See also Carruth and al. (1998), Nickell (1998), Blanchard and Wolfers (2000) and Fitoussi and al. (2000) for empirical results on the interest rate effect on unemployment.
} 


$$
\bar{q}=\frac{d}{(\delta-\sigma A(n+\mu \delta))-\sigma(1-A v) \frac{(\phi \delta+\rho A(n+\mu \delta))}{\rho v-1}}
$$

The interest rate augmentation will be weaker, allowing for an increase in output and hence a depreciation $^{7}$ of the RER to achieve trade balance equilibrium. The RER is directly affected by the monetary policy specification.

Bouveret and al. (2006) put forward a model for a developing country in which the exchange rate is used as a policy tool. The authorities choose a low level of the exchange rate because it raises potential demand and consequently investment. The low level of the exchange rate boosts potential demand, investment and allows a fall in unemployment; in the long run domestic consumption goes up and achieves the equilibrium. Yet the model doesn't take monetary and fiscal policies into account.

Another flaw of equilibrium exchange rates theories is that they don't take history into account. It may be fallacious to think that a country that has experienced a long period of exchange rate overvaluation, a reduced growth rate, an increasing public debt, and a reduced capital stock, that harmed both the employability of its manpower and its exporting sector and increased foreign firms market share will reach the same long-run equilibrium level as if those events had not occurred. Another extension consists of taking hysteresis effects into account (Krugman and Baldwin (1987); Bouveret and Sterdyniak (2005)) where temporary shocks can have long lasting effects (see Gocke (2002) for a discussion of hysteresis in economics). This topic will not be analysed in this article.

The RER can then be contingent on economic policies. However, short-term interest rates are set by Central Banks, whereas these are long-term rates that matter for private agents when they choose to invest and consume. In open economies, studying bond markets linkages is then crucial to understand the links between the internal and external equilibriums.

\section{I.2. Long-term rates in open economies}

Exchange rates are intertwined with interest rates. Indeed, in simple models, the exchange rate is generally deduced from uncovered interest rates parity (UIP) applied to short term rates. What does happen when we take into account long-term interest rates? We should specify how short rates and long ones are set, and how they interact with the exchange rate.

\section{Monetary policy, UIP, long-term rates and RER}

The short-term rate is set by the CB according to its macro-policy goals: inflation and output stabilisation. The exchange rate dynamics is then inferred from UIP:

$$
i_{t}=i_{t}^{*}+\Delta s_{t}^{e}
$$

We assume that the Central Bank follows a Taylor rule, in which the short term rate depends on inflation and output: $i_{t}=\pi_{t}+\lambda_{c b} \cdot\left(\pi_{t}-\pi^{t a r}\right)+\gamma_{c b} \cdot y_{t} \cdot \pi^{t a r}$ is the CB's inflation target. $i_{t}^{*}=\pi_{t}^{*}+\lambda_{c b}^{*}\left(\pi_{t}^{*}-\pi^{t a r *}\right)+\gamma_{c b}^{*} \cdot y_{t}^{*}$ is the foreign short-term interest rate and $\Delta s_{t}^{e}=s_{t+1}^{e}-s_{t}$ is the expected deviation of the exchange rate. Under the UIP hypothesis, the expected deviation of the exchange rate is equal to the spread between domestic and foreign short-term rates. It is conditional on the respective goals of the domestic and foreign Central Banks:

$$
\Delta s_{t}^{e}=i_{t}-i_{t}^{*}=\left(\pi_{t}-\pi_{t}^{*}\right)+\left(\lambda_{c b} \pi_{t}-\lambda_{c b}^{*} \pi_{t}^{*}\right)+\left(\lambda_{c b} \pi^{t a r}-\lambda_{c b}^{*} \pi^{t a r *}\right)+\left(\gamma_{c b} \cdot y_{t}-\gamma_{c b}^{*} \cdot y_{t}^{*}\right)
$$

\footnotetext{
${ }^{7}$ For a broad range of values of the parameters, the denominator is positive, the stability conditions can be sent on demand.
} 
Let $I_{t}$ be the nominal interest rate on a zero-coupon bond maturing in $N$ periods. According to the expectations hypothesis of the term structure of interest rates, and when agents are risk-neutral, the long rate is an average of expected short-term interest ${ }^{8}$ :

$$
I_{t}=\frac{1}{N} \sum_{j=0}^{N-1} i_{t+j}^{e}=\frac{1}{N} \sum_{j=0}^{N-1}\left[\pi_{t+j}^{e}+\lambda_{c b} \cdot\left(\pi_{t+j}^{e}-\pi^{t a r}\right)+\gamma_{c b} \cdot y_{t+j}^{e}\right]
$$

The long rate then depends on the $\mathrm{CB}$ reaction to expected inflation and output. Combining (4) with (5), we get:

$$
I_{t}=\frac{1}{N} \sum_{j=0}^{N-1}\left(i_{t+j}^{* e}+\Delta s_{t+j}^{e}\right)=I_{t}^{*}+\frac{1}{N}\left(s_{t+N-1}^{e}-s_{t}\right)
$$

The domestic long rate is equal to the foreign one plus an expected mean deviation of the exchange rate between $t$ and $t+N-1$. In that model, it is equivalent to speculate between shortterm domestic and foreign bills, or between long-term domestic and foreign bonds (Beenstock and Longbottom (1981)).

Assume that the long rate is a 10 year one. Also assume that agents expect that the convergence to the long run equilibrium will last 10 years. $s_{t+N-1}^{e}$ is the nominal equilibrium exchange rate $\bar{s}$, and $s_{t}=\bar{s}-N .\left(I_{t}-I_{t}^{*}\right)$. Long rates depend on monetary policies goal, then $\bar{s}-s_{t}$ is contingent upon economic policy.

The long run real exchange rate is $q_{t}=\bar{s}+p_{t+N-1}^{* e}-p_{t+N-1}^{e}$. Let us break up the long rate into an expected real long rate $R$ and an expected mean inflation between $t$ and $t+N-1$. It follows:

$$
\bar{q}=s_{t}+p_{t+N-1}^{* e}-p_{t+N-1}^{e}+N .\left(R_{t}+\frac{p_{t+N-1}^{e}-p_{t}}{N}-\left[R_{t}^{*}+\frac{p_{t+N-1}^{* e}-p_{t}^{*}}{N}\right]\right)
$$

then:

$$
\bar{q}-q_{t}=N \cdot\left(R_{t}-R_{t}^{*}\right)
$$

In portfolio equilibrium, the spread between the RER and the ongoing real exchange rate is intertwined with the spread between long-term interest rates. If $\bar{q}$ is not independent of economic policy choices, the determination of the RER is intimately linked to the determination of long-run real long rates in an open economy framework.

\section{Risk aversion, long rates and RER}

Until now, we assumed that the substitution between domestic and foreign financial assets was perfect. Yet, watching international portfolios composition reveals that agents have a strong preference for domestic assets. That empirical assessment is referred to as "home bias" (Tesar and Werner (1994); Lewis (1998)). Empirical tests then reject the hypothesis of perfect substitutability between short-term domestic and foreign assets (Danker and et al. (1987); Benassy A and al. (1992)). A possible explanation is risk aversion (Branson and Henderson (1985); Bleuze and Sterdyniak (1988)).

Let us assume that domestic and foreign financial assets are not substitutable. Equation (4) is then:

$$
i_{t}=i_{t}^{*}+\Delta s_{t}^{e}-\frac{f_{t}}{k}
$$

$f_{t}$ net external financial wealth. The higher $k$, the smaller risk aversion is. It follows:

$$
I_{t}=\frac{1}{N} \sum_{j=0}^{N-1}\left(i_{t+j}^{* e}+\Delta s_{t+j}^{e}\right)=I_{t}^{*}+\frac{1}{N}\left(s_{t+N-1}^{e}-s_{t}-\frac{1}{k} \sum_{j=0}^{N-1} f_{t+j}^{e}\right)
$$

\footnotetext{
${ }^{8}$ See for example Shiller (1979), Campbell and Shiller (1991).
} 
and equation (6) becomes $\bar{q}-q_{t}=N .\left(R_{t}-R_{t}^{*}\right)+\frac{1}{N . k} \sum_{j=0}^{N-1} f_{t+j}^{e}$.

Now the spread between the current real exchange rate and the RER is intertwined with the spread between real long rates and the expected dynamic for the net external financial wealth.

According to (8), the long rate of a small country can durably diverge from foreign long-term interest rates. It hinges upon expected exchange rate deviation, but also on a risk premium if the financial assets substitutability is imperfect on the international scale. Now that risk premium can be very important due to high variability of exchange rates, and to the difficulty (or impossibility) to predict their long run development.

There is no reason for long-term rates equalisation in the long run, in opposition to some works ${ }^{9}$ according to which long-run real long-term rates are determined on the world financial market and should then be equal. Monetary policy can affect long rates and the real exchange rate to achieve its goals.

\section{Part II: RER, fiscal and monetary policies: a model}

This part focuses on the impact of economic policies specification on the RER. We analyze the impact of a permanent demand shock on a small open economy.

\section{II.1. Main characteristics:}

The description of the economy is built on three modelling options: the wage-price loop, the exchange rate determination model and the design of economic policy. Given that those points have been previously analyzed (see for instance Bleuze and Sterdyniak (1988); Benassy and Sterdyniak (1992); Bouveret and Sterdyniak (2005)) we will briefly outline the main characteristic of the model. The wage-price loop is based on the Wage Setting-Price Setting model (Layard and al. (2005)). The use of the WS-PS model appears to be decisive: a permanent shock can have a long-lasting effect on output and the real exchange rate, while in a Phillips framework its effect is temporary.

Regarding exchange rate determination, if investors are unanimous, risk-neutral and infinitely rich, the uncovered interest parity is verified. On the contrary, the portfolio model developed in the article assumes risk-aversion insofar as households demand a risk premium on foreign assets. After a positive demand shock, the domestic economy is stabilized through trade deficits and their impact on the domestic interest rate.

In the model, we make a distinction between short and long term interest rates. Turnovsky (1986) analyzes the term structure of interest rates in a small open economy. Turnovsky introduces neither financial assets dynamics, nor the government budget constraint, and assumes perfect substitutability between financial assets. Sachs and Wyplosz (1984) focus on fiscal policy effects on exchange rates, using the term structure of interest rates. However, they don't analyze the case when the CB follows a monetary policy rule. Taking stock of these issues, we explicitly introduce financial assets dynamics, the government budget constraint, risk-aversion and a monetary policy rule.

\footnotetext{
${ }^{9}$ See Blanchard and Summers (1984) and Barro and Sala-i-Martin (1991).
} 


\section{II.2. Economic Policies:}

The design of economic policies appears to be crucial in our framework. There are two authorities: the government and the CB. Economic policies are conducted following the minimization of loss functions which include the policymakers' targets and instruments. Each policymaker has basically four main targets: stabilizing the output at its potential level (as in the baseline scenario); stabilizing inflation, and meeting the external constraint so that fluctuations in the exchange rate are stabilized, satisfying the intertemporal budget constraint of the government. In addition, policymakers control one instrument and tend to minimize its expensive use. On the one hand, fiscal policy can be costly because of implementation delay, and because it may be irreversible; on the other hand, monetary policy affects future growth through its impact on investment so that using the interest rate can be costly. Moreover, large fluctuations of the short rate can induce undesirable volatility of asset prices on financial markets.

The short term interest rate is set by the $\mathrm{CB}$, while the fiscal policy depends on the government. If we assume that both authorities follow a predetermined rule (such as a Taylor rule for the $\mathrm{CB}$, and a rule stabilizing output and debt for the government), the model is usually time-inconsistent (it matches the closed-loop model case of Oudiz and Sachs (1984)). Policymakers have an incentive to modify their rule over time. We will only consider timeconsistent policies in our model: they result from the minimisation of an intertemporal loss function. Policies are time consistent in the sense that the authorities have no incentive to modify the rule.

Policies derive from the loss function minimisation, following Capoen and al. (2003); the slight difference is that the authors focus on non-cooperative and cooperative behaviour in a three-country model. This article aims at analyzing the effects of economic policies on the real exchange rate; we will therefore only consider the non-cooperative case ${ }^{10}$.

The equilibrium between both authorities is therefore a Nash equilibrium, as the equilibrium between authorities and the market.

The loss functions are:

$$
\operatorname{Min}_{i_{t}} \frac{1}{2} \sum_{t=0}^{\infty} \beta_{C B}^{t}\left(\alpha_{\pi, C B} \cdot \pi_{t}^{2}+\alpha_{y, C B} \cdot y_{t}^{2}+\alpha_{b, C B} \cdot b_{t}^{2}+\alpha_{i, C B} \cdot i_{t}^{2}+\alpha_{g, C B} \cdot g_{t}^{2}\right)
$$

for the $\mathrm{CB}$, and

$$
\operatorname{Min}_{g_{t}} \frac{1}{2} \sum_{t=0}^{\infty} \beta_{G}^{t}\left(\alpha_{\pi, G} \cdot \pi_{t}^{2}+\alpha_{y, G} \cdot y_{t}^{2}+\alpha_{i, G} \cdot i_{t}^{2}+\alpha_{b, G} \cdot b_{t}^{2}+\alpha_{g, G} \cdot g_{t}^{2}\right)
$$

for the government.

Weights put on each goal are summarized in Table 1. The CB seeks to stabilize inflation and output without large swings in the interest rate. The government stabilizes output and to a lesser extent inflation without large swings in public spending and public debt. As a simplification, taxes are set in order to stabilise the debt $\tau_{t}=0,1 b_{t-1}$. The simulated model is intertemporally consistent.

\footnotetext{
${ }^{10}$ Cooperation between the Government and the CB could be achieved by defining a unique loss function (centralised economic policy), or by a Nash-Bargaining procedure. See Capoen and Villa (1997); Capoen and Villa (1998).
} 


\begin{tabular}{c|c|c}
\hline & CB & Government \\
\hline Inflation & 2 & 0.5 \\
Output & 1 & 1 \\
Public debt & 0 & 1 \\
Short-term interest rate & 0.5 & 0 \\
Public expenditures & 0 & 0.5 \\
\hline
\end{tabular}

\section{II.3. The model}

The main equations are summarized in Box 1. Output y is an increasing function of lagged output, public spending $g$, trade balance, household wealth $w$ and a demand shock $d^{11}$. It also negatively depends on taxes $\tau$ and a long-term real interest rate $I-\pi_{L T}^{e}$. Trade balance depends on the difference between domestic and world output and the real exchange rate $p^{*}+s-p$, where $s$ stands for the nominal exchange rate (an increase is depreciation), $p$ and $p^{*}$ are domestic and world prices.

The wage-price loop is a WS-PS loop: the price adjusts slowly to a desired price linked with output, real exchange rate and the long-term rate.

The portfolio model of exchange rate determination implies the uncovered interest parity with a risk premium depending on foreign asset position. The long-term interest rate is set according to the expectations theory of the term structure of interest rate: $\Delta I^{e}=\frac{1-\gamma_{n}}{\gamma_{n}}(I-i)$, with $\gamma_{n}=\gamma \cdot\left(1-\gamma^{n-1}\right) /\left(1-\gamma^{n}\right)$, and $\gamma=\frac{1}{1+\bar{I}}, \bar{I}$ is long run average of yield on an $n$-period bond (Shiller (1979)). The long-term expected inflation rate $\pi_{L T}^{e}$ is a weighted average of future expected inflation rates ${ }^{12}$.

Public debt is the cumulated sum of past fiscal deficits. In the same manner, the net foreign assets position is the cumulated sum of past trade deficits.

Lastly the government and the CB minimise their loss function according to inflation, output, short term interest rate, public debt and public spending.

The variables are expressed as deviations from baseline. The model evolves according to $X_{t+1}=A X_{t}+B U_{t}^{13}$. It is solved to determine time consistent policies ${ }^{14}$.

\footnotetext{
${ }^{11} d$ can be seen as a chock on $\tilde{w}$, the households' desired wealth: if desired wealth depends on the real long rate: $\tilde{w}=a_{0}+a_{1} \cdot\left(I-\pi_{L T}^{e}\right), a_{1}>0$, and if households slowly adjust their wealth to $\tilde{w}$ according to a parameter $b_{1}>0$, then the part of households' consumption that fluctuates with their wealth is $c_{w}=b_{1}\left(w_{-1}-\tilde{w}_{-1}\right)=b_{1}\left(w_{-1}-a_{0}-a_{1} \cdot\left(I-\pi_{L T}^{e}\right)_{-1}\right)$. We get $\sigma=a_{1} \cdot b_{1}, \theta=b_{1}$ and $d=-a_{0} \cdot b_{1}$. A positive permanent chock on $d$ is equivalent to a permanent fall in households' desired wealth.

${ }^{12}$ Eijffinger and al. (2000) Use the same approach to compute a long-term real interest rate.

${ }^{13}$ To simplify, the model is linearised with equilibrium values set at zero. It implies that interest charges on the public debt and net external wealth are not taken into account in simulations.

${ }^{14}$ We use Matlab 7 to simulate the model. The resolution algorithm of rational expectation models with consistent policies is described in Annex I. We have adapted the algorithm of Söderlind (1999) to the case with two authorities. Programs are available from the authors.
} 
The government finances its deficit by issuing short $\left(b_{s t}\right)$ and long term bonds $\left(b_{l t}\right)$ in proportions $\alpha_{s t}$ and $\alpha_{l t} \quad\left(\alpha_{s t}+\alpha_{l t}=1\right)$. Public debt is entirely held by households: $b_{t}=\alpha_{s t} \cdot b_{s t ; t}+\alpha_{l t} \cdot b_{l t ; t}$.

Households are assumed to be risk-neutral when they choose between short and long term bonds. Arbitrage equilibrium implies that the expected return on a domestic long-term bond must equal the short term interest rate. We also assume this condition to be fulfilled in the foreign financial market.

$$
I_{t}=\gamma_{n} I_{t+1}+\left(1-\gamma_{n}\right) \cdot i_{t} \text { et } I_{t}^{*}=\gamma_{n} I_{t+1}^{*}+\left(1-\gamma_{n}\right) \cdot i_{t}^{*}
$$

where $I_{t}^{*}$ and $i_{t}^{*}$ are foreign long and short-term interest rates on foreign bonds $b_{s t}^{*}$ and $b_{l t}^{*}$.

Arbitrage between domestic and foreign assets can be explained by equation (9). $f_{t}=b_{s t, t}^{*}+b_{t t ;}^{*}$ is the net foreign assets stock held in the households' portfolio. Foreign bonds are converted into local currency and stated as a \% of GDP. Households choose to hold short and long-term assets in proportions $\alpha_{s t}^{*}$ and $\alpha_{l t}^{*}$, with $\alpha_{s t}^{*}+\alpha_{l t}^{*}=1$.

Exchange rate dynamics depend on the difference between short-term interest rates and the risk premium. Equation (9) is derived from an open economy portfolio model ${ }^{15}$.

The accumulation equations for public debt, foreign asset and household wealth are:

$$
\begin{aligned}
& b_{t}=\left(1+\alpha_{s t} \cdot i_{t-1}+\alpha_{l t} \cdot I_{t-1}-\pi_{t}\right) \cdot b_{t-1}+g_{t-1}-\tau_{t-1} \\
& f_{t}=\left(1+\alpha_{s t}^{*} \cdot i_{t-1}^{*}+\alpha_{l t}^{*} \cdot I_{t-1}^{*}-\pi_{t}+\left(s_{t}-s_{t-1}\right)\right) \cdot f_{t-1}+b c_{t-1} \\
& w_{t}=b_{t}+f_{t}
\end{aligned}
$$

Return on public debt depends on a mean interest rate, according to the financing structure if the government. The interest rate on external debt depends on a mean interest rate according to the portfolio structure in foreign assets chosen by the households.

\section{II.4 The long run}

In the long run, trade balance must be in equilibrium so as to stabilize external debt. The real exchange rate then achieves equilibrium. If the shock effect is transitory, the real exchange rate returns to its baseline value. On the other hand, if the demand shock has permanent positive (negative) effects on output, the real exchange must depreciate (appreciate) to restore the trade balance.

In portfolio models with WS-PS, the stabilisation of the economy hinges upon monetary policy: the reduction of the net foreign assets position implies an increase in the short-term interest rate so as to lead households to sell their foreign assets. Yet this increase has a direct impact on inflation through its effects on costs. The increase in the interest rate entails a permanent increase of inflation, which improves output. External equilibrium implies a real depreciation of the exchange rate in order to offset the increase of imports due to output expansion.

\footnotetext{
${ }^{15}$ Proof is available from the authors.
} 
Goods market equilibrium

$$
\begin{array}{ll}
y_{t}=c \cdot y_{t-1}+d+g_{t-1}-\varpi \cdot \tau_{t-1}-\sigma\left(I-\pi_{L T}^{e}\right)_{t-1}+\theta \cdot w_{t-1}+b c_{t} & c=\sigma=\varpi=0,5 ; \theta=0.25 \\
b c_{t}=n\left(y_{t}^{*}-y_{t}\right)+n \delta\left(p_{t}^{*}+s_{t}-p_{t}\right) & \delta=2 ; n=0,25
\end{array}
$$

Wage price loop

$$
\pi_{t}=\lambda\left[n\left(s_{t}+p_{t}^{*}\right)+(1-n) p_{t}+\mu \cdot y_{t}+v\left(I-\pi_{L T}^{e}\right)_{t-1}-p_{t-1}\right] \quad \mu=0,4 ; \quad v=0,2 ; \lambda=0,25
$$

Financial market equilibrium

$$
\begin{array}{ll}
f_{t}=k\left(s_{t+1}^{e}-s_{t}+i_{t}^{*}-i_{t}\right) & k=4 \\
I_{t+1}=\frac{1}{\gamma_{n}} I_{t}-\frac{1-\gamma_{n}}{\gamma_{n}} i_{t} & \gamma_{n}=0,9 \\
\pi_{L T ; t+1}^{e}=\frac{1}{\gamma_{n}} \cdot \pi_{L T ; t}^{e}-\frac{1-\gamma_{n}}{\gamma_{n}} \cdot \pi_{t} &
\end{array}
$$

Wealth and financial assets accumulation

$$
\begin{aligned}
& b_{t}=\left(1+i_{t}-\pi_{t}\right) \cdot b_{t-1}+g_{t-1}-\tau_{t-1} \\
& f_{t}=\left(1+i_{t-1}^{*}-\pi_{t}+\left(s_{t}-s_{t-1}\right)\right) \cdot f_{t-1}+b c_{t-1} \\
& w_{t}=b_{t}+f_{t}
\end{aligned}
$$

CB loss function

$$
\operatorname{Min}_{i_{t}} \frac{1}{2} \sum_{t=0}^{\infty} \beta_{C B}^{t}\left(\alpha_{\pi, C B} \cdot \pi_{t}^{2}+\alpha_{y, C B} \cdot y_{t}^{2}+\alpha_{i, C B} \cdot i_{t}^{2}+\alpha_{f, C B} \cdot f_{t}^{2}+\alpha_{g, C B} \cdot g_{t}^{2}\right) \quad \beta_{C B}=0,99
$$

Government loss function

$$
\operatorname{Min}_{g_{t}} \frac{1}{2} \sum_{t=0}^{\infty} \beta_{G}^{t}\left(\alpha_{\pi, G} \cdot \pi_{t}^{2}+\alpha_{y, G} \cdot y_{t}^{2}+\alpha_{i, G} \cdot i_{t}^{2}+\alpha_{f, G} \cdot f_{t}^{2}+\alpha_{g, G} \cdot g_{t}^{2}\right) \quad \beta_{G}=0,99
$$

\section{Part III Some simulations}

\section{III.1. The baseline scenario}

We analyze the impact of a 1\%-of-GDP permanent private demand increase on the economy. Results are depicted on Figure 1.

Demand shock increases output. The nominal exchange rate overshoots in the short run and appreciates. The rise in output leads to a trade deficit and to a worsening of the 
foreign assets position. The interest rate augments because of growing inflation and output. Then the nominal exchange rate depreciates to restore the trade balance and to stabilize the real exchange rate. In the long run, there is a permanent increase in output because the rise in the interest rate is not sufficient to weaken inflation. The trade balance equilibrium is achieved through a real depreciation of the exchange rate. The rise in the short term interest rate is expected by the market and leads to an increase in the long term interest rate. The positive effect on output allows for a decrease in public spending and public debt.

In this framework a permanent demand shock has a permanent effect on output and the RER, these results are similar to Bouveret and Sterdyniak (2005), who focus on Taylor's rule (see Box 2). Long-run values are summarized in Table 2.

\section{Figure $1.1 \%$ private demand shock}
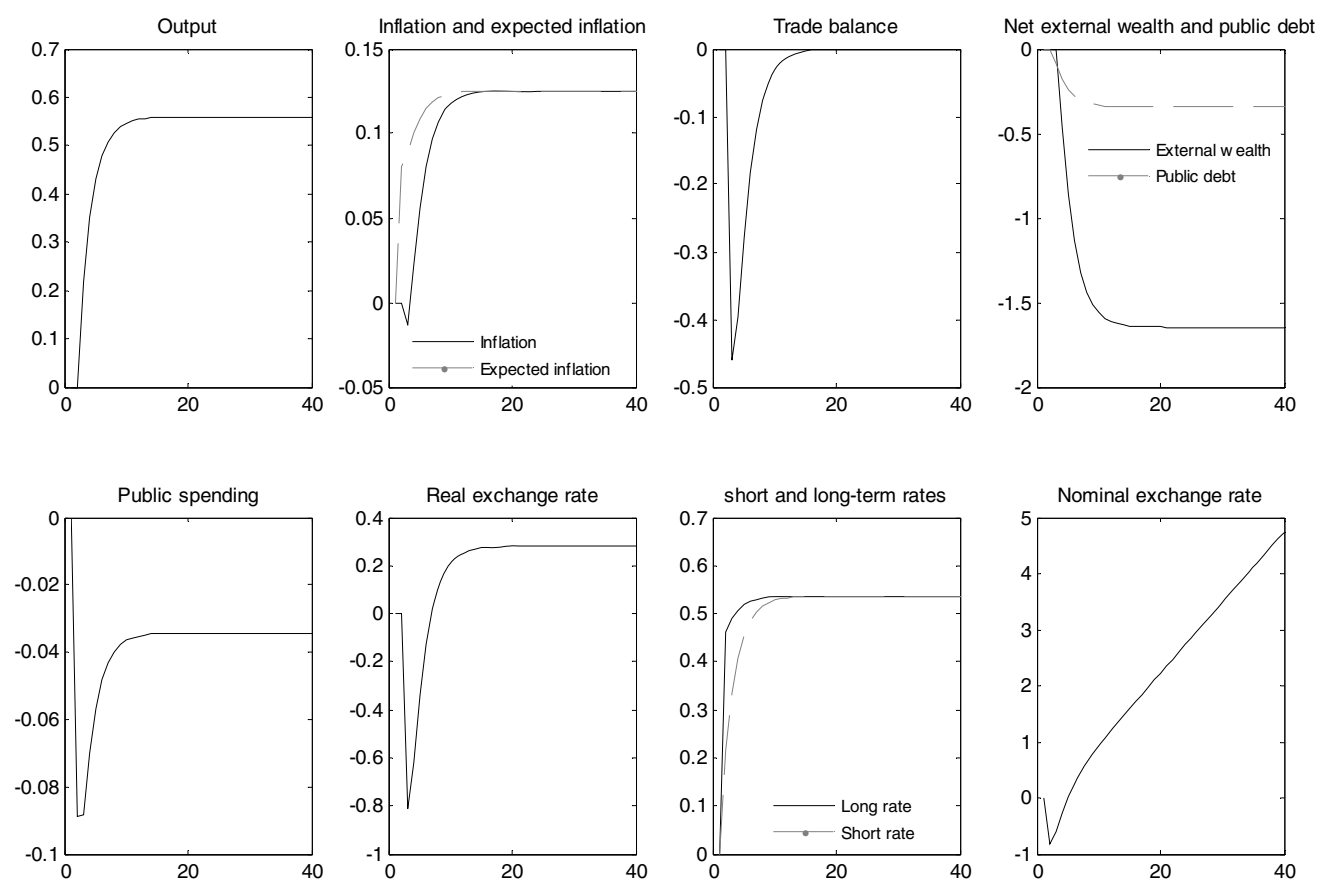

Source: Authors' calculations. 


\begin{tabular}{|c|c|}
\hline \multicolumn{2}{|c|}{ Table 2 .Long run values } \\
\hline Variable & Value \\
\hline Output & 0.56 \\
\hline Inflation & 0.13 \\
\hline Net foreign assets & -1.65 \\
\hline Short-term rate & 0.54 \\
\hline Exchange rate & + \\
\hline Exchange rate variation & 0.13 \\
\hline Real exchange rate & 0.28 \\
\hline Public debt & -0.34 \\
\hline Public spending & -0.03 \\
\hline Long-term rate & 0.54 \\
\hline
\end{tabular}

Source: Authors' calculations. 


\section{Box 2. Time-consistent policy vs Taylor's rule}

We compare the baseline scenario to a variant in which the CB sets its short-term rate according to the following Taylor's rule:

$$
r_{t}=\rho p_{t}+\phi y_{t} \text { avec } \rho=1.5, \phi=0.5
$$

The government fixes taxes and public spending according to :

$$
\left\{\begin{array}{l}
\tau_{t}=0,1 \cdot b_{t} \\
g_{t}=-0,3 \cdot y_{t}
\end{array}\right.
$$

The results are outlined in Figure 2. As expected, the time consistent policy stabilizes the economy more efficiently: output is higher and fluctuations are lower while in the Taylor's rule framework variables fluctuate more.

Figure 2. Comparison of Time-consistent policy and a Taylor rule
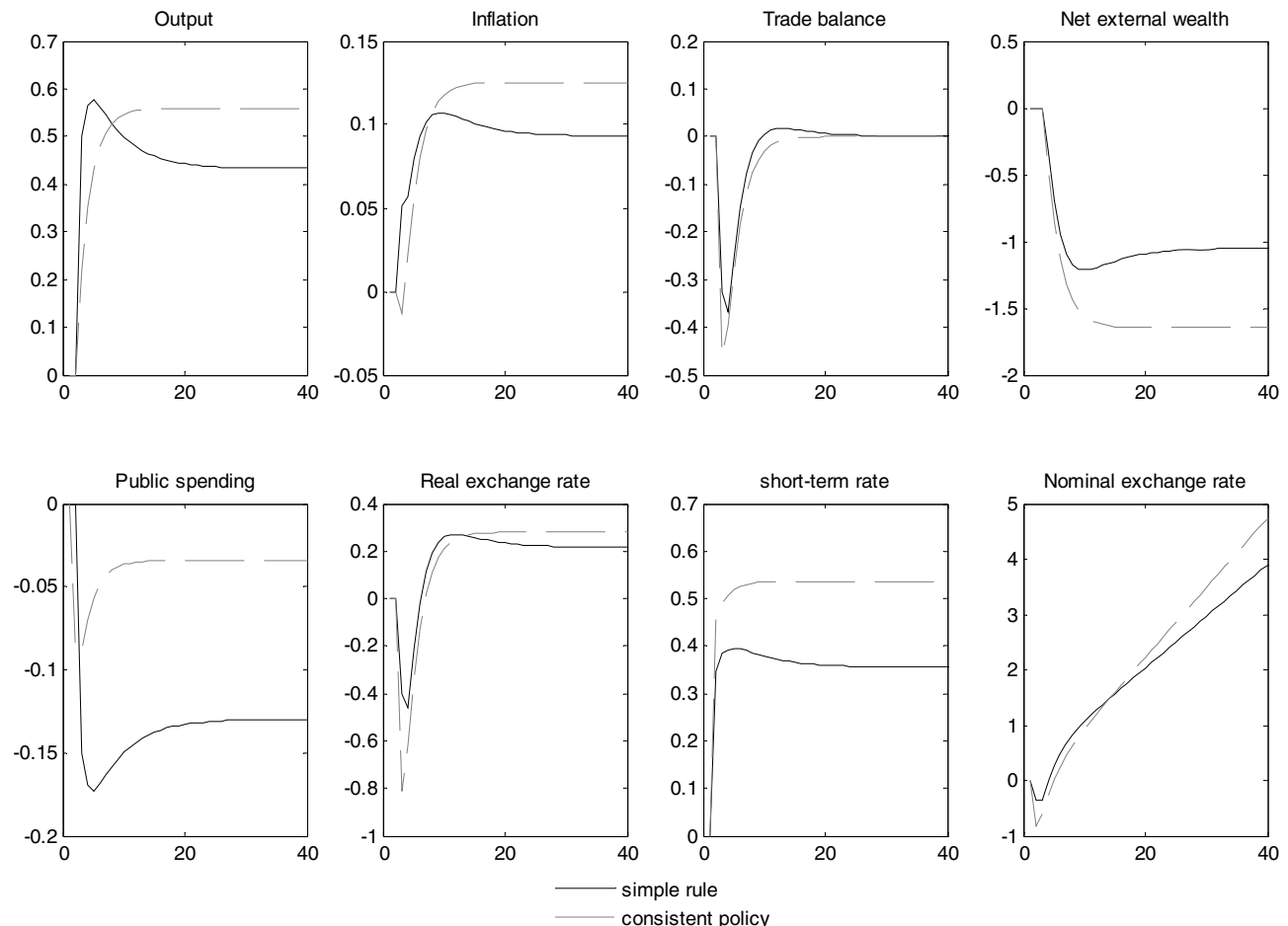

Source: Authors’ calculations. 


\section{III.2. Some Variants}

The model can be used in order to assess the impact of policymakers' objectives on the RER. In variant 1 , the CB puts a higher weight on output stabilisation: $\alpha_{y, C B}=2$. The CB increases its interest rate which in turn affects the long-term interest rate, reducing the impact of the demand shock on output and inflation. The real exchange rate depreciates less to stabilise the trade balance and the net foreign assets position (see Table 3).

In variant 2, the government puts more weight on output's stabilisation $\alpha_{y, G}=2$. Public debt decreases, leading to a weaker effect on output in the long run. The CB can in turn increase its interest rate by a smaller margin.

We then put successively $\alpha_{q, C B}=1, \alpha_{f, C B}=1, \alpha_{q, G}=1$ et $\alpha_{f, G}=1$. In variant 3 , the CB puts a positive weight to the real exchange rate. There is a trade-off between the real exchange rate and the other objectives. After a positive demand shock, the RER is weaker in the long run compared to the baseline scenario, with higher interest rates and lower inflation and output.

In variant 4 , the $\mathrm{CB}$ puts a positive weight on the net foreign assets position; the RER depreciates more in the long run because of the weaker increase in the interest rate. The government lowers its debt to stabilize output and inflation.

In variants 5 and 6 we modify the government's objectives. In variant 5 it stabilizes the real exchange rate and lowers its debt, reducing inflation, lowering the interest rate hike and the real exchange rate. In variant 6 it seeks to stabilise the net foreign assets position. There is a larger lowering of public debt, reducing the increase in output and interest rate and inflation. The real exchange rate depreciates less in the long run

The RER then strongly depends on CB and government objectives. The results also show that interest rates and RER are intertwined: higher RER (depreciated RER) in the long run are coupled with lower real interest rates and a higher inflation rate.

\section{Table 3. Long run value and Policymakers' preferences}

\begin{tabular}{|l|c|c|c|c|c|c|c|}
\hline Variable & $\begin{array}{c}\text { Baseline } \\
\text { scenario }\end{array}$ & $\begin{array}{c}\text { Variant 1 } \\
\alpha_{y, C B}=2\end{array}$ & $\begin{array}{c}\text { Variant 2 } \\
\alpha_{y, G}=2\end{array}$ & $\begin{array}{c}\text { Variant 3 } \\
\alpha_{q, C B}=1\end{array}$ & $\begin{array}{c}\text { Variant 4 } \\
\alpha_{f, C B}=1\end{array}$ & $\begin{array}{c}\text { Variant 5 } \\
\alpha_{q, G}=1\end{array}$ & $\begin{array}{c}\text { Variant 6 } \\
\alpha_{f, G}=1\end{array}$ \\
\hline RER & 0.280 & 0.167 & 0.262 & 0.173 & 0.566 & 0.258 & 0.245 \\
\hline Long rate & 0.537 & 0.606 & 0.482 & 0.616 & 0.352 & 0.533 & 0.489 \\
\hline Inflation & 0.125 & 0.093 & 0.116 & 0.095 & 0.208 & 0.118 & 0.111 \\
\hline $\begin{array}{l}\text { Real long-term } \\
\text { interest rate }\end{array}$ & 0.412 & 0.513 & 0.366 & 0.521 & 0.144 & 0.415 & 0.378 \\
\hline
\end{tabular}

Source: Authors' calculations.

\section{III.3. The wage-price loop and inflation illusion: A reappraisal}

We assumed a WS-PS loop with a slow adjustment of prices to desired prices. Yet in the long run there is a gap between effective and desired prices, implying a permanent inflation illusion (Debonneuil and Sterdyniak (1984)). If we now assume the desired price will adjust according to expected inflation:

$$
p_{t}=p_{t-1}+\pi_{t}^{e}+\lambda\left[n\left(s_{t}+p_{t}^{*}\right)+(1-n) p_{t}+\mu \cdot y_{t}+v\left(I-\pi_{L T}^{a}\right)_{t-1}-p_{t-1}-\pi_{t}^{e}\right]
$$

Expected inflation for the firms adjusts slowly to past inflation: 


$$
\pi_{t}^{e}=\lambda_{e} \cdot \pi_{t-1}^{e}+\left(1-\lambda_{e}\right) \pi_{t-1} \quad \lambda_{e}=0,25
$$

The higher the $\lambda_{e}$ value, the faster the firms adjust their inflation expectation. In the long run there is no inflation illusion. Output, public spending and net foreign assets decrease, inflation and interest rates increase (Figure 3).

The level of the RER doesn't depend on $\lambda_{e}$. We simulate the previous variants with $\lambda_{e}=0.25$; the RER appears to be less dependent on policymakers' preferences (Table 4). The RER is strongly linked with the weights on net foreign assets. When the CB seeks to stabilise NFA (variant 4), it leads to a fall in inflation, a decrease of the interest rate and a higher RER appreciation. On the other hand when the Government stabilizes NFA (variant 6) the RER appreciation is lower than in the baseline scenario.

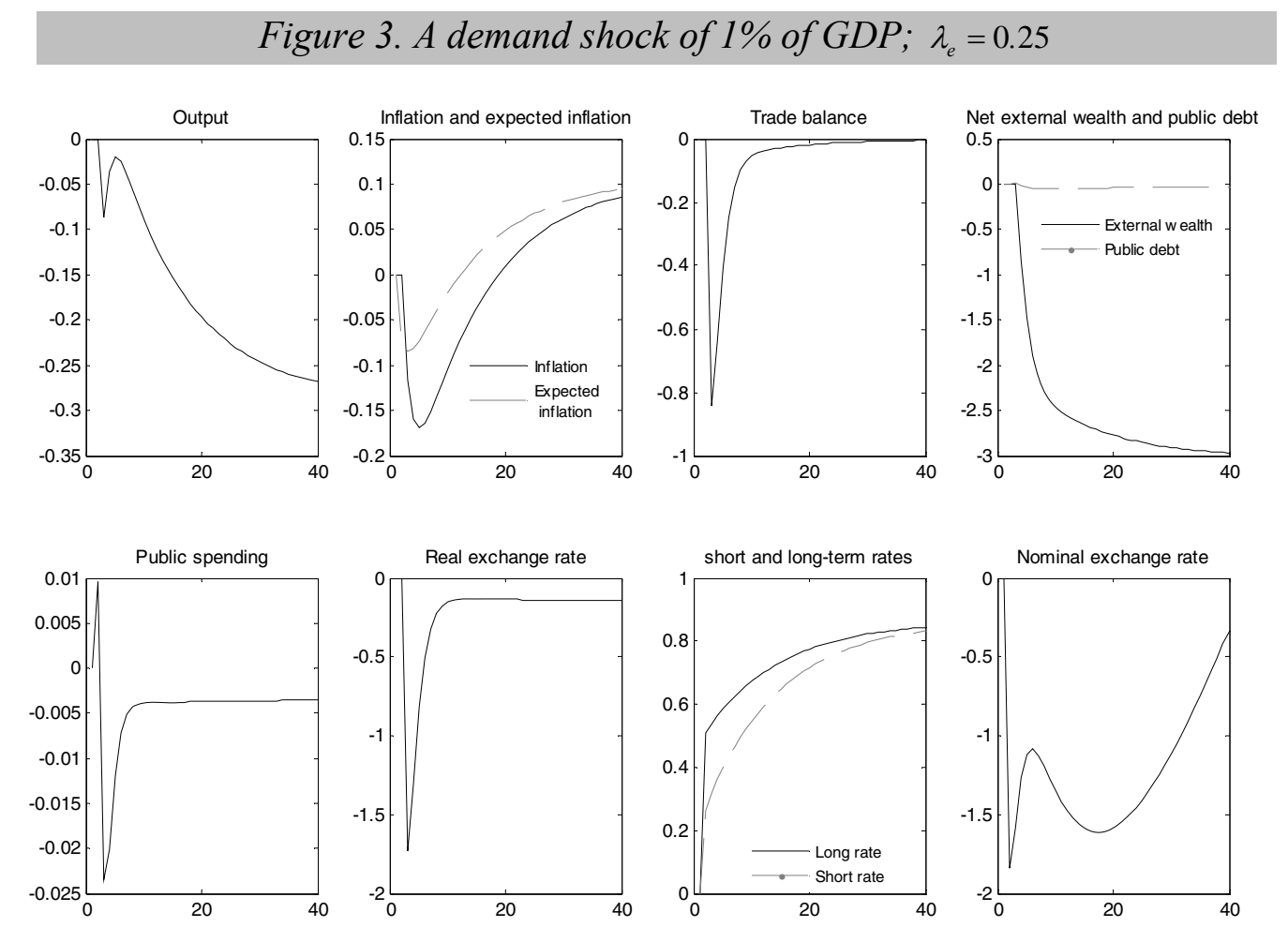

Source: Authors’ calculations. 
Table 4. Long run values and Policymakers'preferences $-\lambda_{e}=0.25$

\begin{tabular}{|l|c|c|c|c|c|c|c|}
\hline Variable & $\begin{array}{c}\text { Baseline } \\
\text { scenario }\end{array}$ & $\begin{array}{c}\text { Variant 1 } \\
\alpha_{y, B C}=2\end{array}$ & $\begin{array}{c}\text { Variant 2 } \\
\alpha_{y, G}=2\end{array}$ & $\begin{array}{c}\text { Variant 3 } \\
\alpha_{q, B C}=1\end{array}$ & $\begin{array}{c}\text { Variant 4 } \\
\alpha_{f, B C}=1\end{array}$ & $\begin{array}{c}\text { Variant 5 } \\
\alpha_{q, G}=1\end{array}$ & $\begin{array}{c}\text { Variant 6 } \\
\alpha_{f, G}=1\end{array}$ \\
\hline $\begin{array}{l}\text { Real exchange } \\
\text { rate }\end{array}$ & -0.144 & -0.144 & -0.144 & -0.145 & -0.158 & -0.144 & -0.055 \\
\hline Long rate & 0.862 & 0.845 & 0.858 & 0.781 & 0.189 & 0.856 & 0.351 \\
\hline Inflation & 0.107 & 0.089 & 0.102 & 0.019 & -0.640 & 0.101 & 0.062 \\
\hline
\end{tabular}

Source : Authors' calculations.

\section{Conclusion}

In the equilibrium exchange rate theories' framework, economic policy is given, and assumed to be committed to an internal equilibrium which is independent of the RER. The hypotheses of independence between the RER, the internal equilibrium and economic policies are highly debatable. This article shows that removing those hypotheses can have a strong impact on the RER.

We put forward a model in which the RER that stabilises the NFA position and economic policies are time-consistent. We show that in a portfolio model and a WS-PS setting, the RER depends strongly on policymakers' preferences. If after a positive demand shock, the CB wants to stabilise the real exchange rate, the depreciation of the RER is lower than in the baseline scenario. When the CB seeks to stabilise the NFA position, inflation and output are higher in the long run. The RER directly hinges on the design of economic policies; it is not unique and contingent upon policymakers' preferences: for each preference set there is a corresponding equilibrium exchange rate.

With regard to equilibrium exchange rate theories, our results weaken the legitimacy of those approaches to exchange rate determination: if the RER level is conditional on economic policies, how can we use models without specification of economic policies?

We can refer to Robinson (1937) who claimed more than fifty years ago:

"It is now obvious that there is no one rate of exchange which is the equilibrium rate corresponding to a given state of world demands and techniques; in any given situation there is an equilibrium rate corresponding to each rate of interest and level of effective demand, and any rate of exchange, within very wide limits, can be turned into the equilibrium rate by altering the rate of interest appropriately. Moreover, any rate of exchange can be made compatible with any rate of interest provided that money wages can be sufficiently altered. The notion of the equilibrium exchange rate is a chimera. The rate of exchange, the rate of interest, the level of effective demand and the level of money wages react upon each other like the balls in Marshall's bowl, and no one is determined unless all the rest are given." 


\section{Annex I. Solution of RE linear models with time-consistent policy and two authorities}

We present the method to solve RE linear model with time consistent economic policy proposed by Backus and Driffill (1986) and implemented by Söderlind (1999). The method is modified to take into account two independent policymakers, which can have different loss functions, as in Oudiz and Sachs (1984) and Capoen and Villa (1997). We use Söderlind's notations.

Assume an economy evolving according to:

$$
\left[\begin{array}{c}
x_{1 t+1} \\
x_{2 t+1}
\end{array}\right]=A\left[\begin{array}{l}
x_{1 t} \\
x_{2 t}
\end{array}\right]+B u_{t}
$$

where $x_{1 t}$ is a $n_{1} \times 1$ vector of predetermined variables, and $x_{2 t}$ is a $n_{2} \times 1$ vector of forward-looking variables. $u_{t}$ is a $k \times 1$ vector of instruments of economic policy. $x_{t}$ is the $n=n_{1}+n_{2}$ dimension vector $\left[\begin{array}{l}x_{1 t} \\ x_{2 t}\end{array}\right]$.

The government $G$ and the Central Bank $C B$ have the following loss functions:

$$
\begin{aligned}
& J_{G, 0}=E_{0} \sum_{t=0}^{\infty} \beta_{G}^{t}\left(x_{t}^{\prime} Q_{G} x_{t}+2 x_{t}^{\prime} U_{G} u_{t}+u_{t}^{\prime} R_{G} u_{t}\right) \\
& J_{C B, 0}=E_{0} \sum_{t=0}^{\infty} \beta_{C B}^{t}\left(x_{t}^{\prime} Q_{C B} x_{t}+2 x_{t}^{\prime} U_{C B} u_{t}+u_{t}^{\prime} R_{C B} u_{t}\right)
\end{aligned}
$$

In period $t$, the two authorities set there instruments so as to minimise their respective loss functions, taking into account private sector expectations for the future. The private sector perfectly expects future economic policies. It ensures that the government and the Central Bank undertake time-consistent policies: policies announced in $t$ for $t+1$ will be implemented in $t+1$, because when the authorities minimise their loss functions in $t+1$, the announced policy in $t$ is the best given private expectations for $t+2$.

The linear quadratic form of the model implies that the solution for $t+1$ gives for each authority $j$ a value function that is quadratic in the state variables $x_{1 t+1}^{\prime} V_{j, t+1} x_{1 t+1}+v_{j, t+1}$, and a linear relation between the forward-looking variables and the backward-looking ones $x_{2 t+1}=C_{t+1} x_{1 t+1}$. The authorities' value functions in $t$ then satisfy the following Bellman equations:

$$
x_{1 t}^{\prime} V_{j, t} x_{1 t}+v_{j, t}=\min _{u_{j, t}}\left[x_{t}^{\prime} Q_{j, t} x_{t}+2 x_{t}^{\prime} U_{j} u_{t}+u_{t}^{\prime} R_{j} u_{t}+\beta E_{t}\left(x_{1 t+1}^{\prime} V_{j, t+1} x_{1 t+1}+v_{j, t+1}\right)\right] \quad j=G, B C
$$

with constraints:

$$
\begin{aligned}
& E_{t} x_{2 t+1}=C_{t+1} E_{t} x_{1 t+1} \\
& \text { equation (12), } \\
& \text { and } x_{1 t} \text { given. }
\end{aligned}
$$

Combining (12) and (15), and injecting the result in (14), we get :

$$
x_{2 t}=D_{t} x_{1 t}+G_{t} u_{t}
$$




$$
\begin{aligned}
& x_{1 t}^{\prime} V_{j, t} x_{1 t}+v_{j, t}=\min _{u_{j, t}}\left[x_{1 t}^{\prime} Q_{j, t}^{*} x_{t 1}+2 x_{t 1}^{\prime} U_{j, t}^{*} u_{t}+u_{t}^{\prime} R_{j, t}^{*} u_{t}+\beta E_{t}\left(x_{1 t+1}^{\prime} V_{j, t+1} x_{1 t+1}+v_{j, t+1}\right)\right] \\
& \text { s.c. } x_{1 t+1}=A_{t}^{*} x_{1 t}+B_{t}^{*} u_{t}
\end{aligned}
$$

Then we obtain the following system of matrices:

$$
\left\{\begin{array}{l}
D_{t}=\left(A_{22}-C_{t+1} A_{12}\right)^{-1}\left(C_{t+1} A_{11}-A_{21}\right) \\
G_{t}=\left(A_{22}-C_{t+1} A_{12}\right)^{-1}\left(C_{t+1} B_{1}-B_{2}\right) \\
A_{t}^{*}=A_{11}+A_{12} D_{t} \\
B_{t}^{*}=B_{1}+A_{12} G_{t} \\
Q_{j, t}^{*}=Q_{j, 11}+Q_{j, 12} D_{t}+D_{t}^{\prime} Q_{j, 21}+D_{t}^{\prime} Q_{j, 22} D_{t} \\
U_{j, t}^{*}=Q_{j, 12} G_{t}+D_{t}^{\prime} Q_{j, 22} G_{t}+U_{1}+D_{j, t}^{\prime} U_{2} \\
R_{j, t}^{*}=R_{j}+G_{t}^{\prime} Q_{j, 22} G_{t}+G_{t}^{\prime} U_{j, 2}+U_{j, 2}^{\prime} G_{t}
\end{array}\right\}
$$

Deriving (16) successively in respect to instruments $j$ contained in vector $u$, we get the following first-order conditions:

$$
\begin{aligned}
& u_{t}=-F_{1 t} x_{1 t} \\
& F_{1 t}=\left(R_{j, t}^{* \prime}+\beta B_{j, t}^{* \prime} V_{j, t+1} B_{t}^{*}\right)^{-1}\left(U_{j, t}^{* \prime}+\beta B_{j, t}^{* \prime} V_{j, t+1} A_{t}^{*}\right) \\
& x_{2 t}=C_{t} x_{1 t} \quad \text { avec } C_{t}=D_{t}-G_{t} F_{1 t}
\end{aligned}
$$

The first line of $F_{1 t}$ includes the derivatives with respect to the first instrument of authority $j$, the second one contains derivatives with respect to the second instrument of authority $j$ and so on. Combining (18) and (20) in (16), we get :

$$
V_{j, t}=Q_{j, t}^{*}-U_{j, t}^{*} F_{1 t}-F_{1 t}{ }^{\prime} U_{j, t}^{*}{ }^{\prime}+F_{1 t}{ }^{\prime} R_{j, t}^{*} F_{1 t}+\beta\left(A_{t}^{*}-B_{t}^{*} F_{1 t}\right)^{\prime} V_{j, t+1}\left(A_{t}^{*}-B_{t}^{*} F_{1 t}\right)
$$

The system composed of equations (17) to (21) is iterated until convergence is achieved (algorithm 'backward in time'). We then obtain the following system:

$$
\begin{aligned}
& x_{1 t}=\left(A_{11}+A_{12} C-B_{1} F_{1}\right) \cdot x_{1 t-1} \\
& x_{2 t}=C \cdot x_{1 t} \\
& u_{t}=-F_{1} \cdot x_{1 t}
\end{aligned}
$$




\section{References}

Artis, M. and M. P. Taylor (1993) "DEER Hunting - Misalignment, Debt Accumulation, and Desired Equilibrium Exchange Rates." IMF Working Paper 93-48.

Backus, D. and J. Driffill (1986) "The Consistency of Optimal Policy in Stochastic Rational Expectations Models". Discussion paper. London, CEPR. 124.

Barro, R. J. and X. Sala-i-Martin (1991) "World real interest ates". NBER Working Paper Series, National Bureau of Economic Research. 3317.

Bayoumi, T., P. B. Clark and S. Symansky (1994) "Robustness of Equilibrium Exchange Rate Calculations to Alternative Assumptions and Methodologies." IMF Working Paper 94-17.

Beenstock, M. and J. A. Longbottom (1981) "The term structure of interest rates In a small open economy." Journal of Money, Credit and Banking 13 (1): 44-59.

Benassy A, M. Fiole, E. Fourmann and H. Sterdyniak (1992) "De la flexibilité des taux de change et de ses conséquences macroéconomiques." Observations et Diagnostics Économiques 40: 201-248.

Benassy, A. and H. Sterdyniak (1992) "La détermination des taux d'intérêt dans les modèles multinationaux : l'état de l'art "Economie et Prévision 104 (3).

Blanchard, O. and J. Wolfers (2000) "The role of shocks and institutions in the rise of European unemployment: The aggregate evidence." Economic Journal 110 462: C1-33.

Blanchard, O. J. and L. H. Summers (1984) "Perspectives on high world real interest rates." Brookings Papers on Economic Activity 2: 273-324.

Bleuze, E. and H. Sterdyniak (1988) "L'interdépendance des économies en change flexible: les apports d'une maquette dynamique." Revue Economique 39 (5).

Blundell-Wignall, A. and F. Browne (1991) "Increasing financial market integration, real exchange rates and macroeconomic adjustment". OECD Working Papers, OECD Economics Department. 96.

Bouveret, A., S. Mestiri and H. Sterdyniak (2006) " La valeur du Yuan. Les paradoxes du taux de change d'équilibre " Revue de l'OFCE 98: 77-127.

Bouveret, A. and H. Sterdyniak (2005) "Les modèles de taux de change. Equilibre de long terme, dynamique et hystérèse." Revue de l'OFCE 93: 245-286.

Branson, W. (1979) "Exchange Rate Dynamics and Monetary Policy." in A. Lindbeck Inflation and Employment in Open Economies, , North-Holland.

Branson, W. and D. W. Henderson (1985) "The specification and influence of asset markets." in P. B. Kenen and R. W. Jones. Handbook of International Economics. Amsterdam, North Holland.

Campbell, J. Y. and R. J. Shiller (1991) "Yield spreads and interest rate movements: A bird's eye view." Review of Economic Studies 58 3: 495-514.

Capoen, F., J. Creel, P. Cussy and H. Lenoble-Liaud (2003) "How to Manage Financial Shocks: Intra-European vs. International Monetary Coordination." Journal of Macroeconomics 25 (4): 431-55.

Capoen, F. and P. Villa (1997) "Internal and External Policy Coordination: a Dynamic Analysis", CEPII research center. 97-15. 
Capoen, F. and P. Villa (1998) "Coordination interne et externe de la politique economique: Une analyse dynamique. (Internal and External Policy Coordination: A Dynamic Analysis. With English summary.)." Revue Economique 49 3: 655-64.

Carruth, A. A., M. A. Hooker and A. J. Oswald (1998) "Unemployment equilibria and input prices: Theory and evidence from the United States." Review of Economics and Statistics 80 4: 621-28.

Chagny, O., F. Reynès and H. Sterdyniak (2002) "The equilibrium rate of unemployment : a theoretical discussion and an empirical evaluation for six OECD countries". Document de Travail, Observatoire Francais des Conjonctures Economiques (OFCE). 2002-04.

Clark, P. B. and R. MacDonald (1998) "Exchange Rates and Economic Fundamentals - A Methodological Comparison of BEERs and FEERs " IMF Working Paper 98-67.

Cumby, R., E and M. Obstfeld (1982) "International interest-rate and price-level linkages under flexible exchange rates: A review of recent evidence". NBER Working Paper Series, National Bureau of Economic Research. 921.

Danker, D. J. and et al. (1987) "Small empirical models of exchange market intervention: Applications to Germany, Japan, and Canada." Journal of Policy Modeling 9 1: 143-73.

Debonneuil, M. and H. Sterdyniak (1984) "La boucle prix-salaires dans l'inflation." Revue Economique 35 2: 267-311.

Eijffinger, S. C. W., E. Schaling and W. Verhagen (2000) "The term structure of interest rates and inflation forecast targeting", C.E.P.R. Discussion Papers. 2375.

Fitoussi, J.-P., D. Jestaz, E. S. Phelps and G. Zoega (2000) "Roots of the recent recoveries: Labor reforms or private sector forces?" Brookings Papers on Economic Activity 1: 237-91.

Frankel, J., A (1991) "Quantifying international capital mobility in the 1980s". NBER Working Paper Series, National Bureau of Economic Research. 2856.

Gocke, M. (2002) "Various Concepts of Hysteresis Applied in Economics." Journal of Economic Surveys 16 (2): 167-88.

Joly, H., C. Prigent and N. Sobczak (1996) " Le taux de change réel d'équilibre. Une introduction." Economie et Prévision 123-124: 1-21.

Kasman, B. and C. Pigott (1988) "Interest rate divergences among the major industrial nations." Federal Reserve Bank of New York Quarterly Review 13 3: 28-44.

Krugman, P. R. and R. E. Baldwin (1987) "The Persistence of the U.S. Trade Deficit." Brookings Papers on Economic Activity 1: 1-43.

Kydland, F. E. and E. C. Prescott (1977) "Rules rather than discretion: The inconsistency of optimal plans." Journal of Political Economy 85 3: 473-91.

Layard, R., S. Nickell and R. Jackman (2005) Unemployment: Macroeconomic Performance and the Labour Market. BookOxford University Press: Oxford.

Lewis, K., K (1998) "International home bias in international finance and business cycles". NBER Working Paper Series, National Bureau of Economic Research. 6351.

Mishkin, F. S. (1984) "The real interest rate: A multi-country empirical study." Canadian Journal of Economics 17 2: 283-311.

Nickell, S. (1998) "Unemployment: questions and some answers." Economic Journal 108 448: 802-16. 
Oudiz, G. and J. Sachs (1984) "Macroeconomic Policy Coordination among the Industrial Economies." Brookings Papers on Economic Activity 1: 1-64.

Pigott, C. (1993) "International interest rate convergence: A survey of the issues and evidence." Federal Reserve Bank of New York Quarterly Review 18 4: 24-37.

Robinson, J. (1937) "The foreign exchanges." in. Essays in the theory of Employment. London, MacMillan.

Sachs, J. and C. Wyplosz (1984) "Real exchange rate effects of fiscal policy". NBER Working Paper Series, National Bureau of Economic Research. 1255.

Shiller, R. J. (1979) "The volatility of long-term interest rates and expectations models of the term structure." The Journal of Political Economy 87 (6): 1190-1219.

Söderlind, P. (1999) "Solution and estimation of RE macromodels with optimal policy." European Economic Review 43 4-6: 813-23.

Stein, J. L. and P. Allen (1995) Fundamental Determinants of Exchange Rates. Oxford University Press.

Tesar, L., L and I. Werner, M (1994) "International equity transactions and U.S. portfolio choice". NBER Working Paper Series, National Bureau of Economic Research. 4611.

Throop, A. W. (1994) "International financial market integration and linkages of national interest rates." Federal Reserve Bank of San Francisco Economic Review 3: 3-18.

Turnovsky, S. J. (1986) "Short-term and long-term interest rates in a monetary model of a small open economy." Journal of International Economics 20 3/4: 291-311.

Williamson, J. (1985) The Exchange Rate System. Institute for International Economics: Washington D.C. 